\title{
Bordj Hamza, description, pathology and restoration
}

\author{
S. Messikh \\ Department of Architecture, University Saad Dahleb Blida, Algeria
}

\begin{abstract}
The fortress of Bouira Bordj Hamza is one of the last Ottoman fortresses in the region of Kabylie in Algeria, which remain more or less preserved and not processed. It was built during the reign of the pasha Hassan Corso who ordered between 1540 and 1541 the implant of several fortifications at strategic points in the territory of Constantine to control and monitor the Eastern territory. The fort is the only one authentic monument in this site and later on the city of Bouira, town built for the French settlers, close to it. It was the scene of clashes between the Ottoman and the Kabyle tribes rebelled against the regency and between the Algerians and the French troops until 1871. The fort suffered from much destruction between the $19^{\text {th }}$ and $20^{\text {th }}$ Century while some restorations occurred at the same period of time. After the Algerian independence it was abandoned and looted from its materials, then squatted and turned into a slum which caused its destruction and only its imposing outer wall is still standing. Today, the restorations of the walls are in progress, the project consists of the repair and the strengthening of the masonry structures of the enclosure and also on the rediscovery of archaeological remains inside the fort under the over time accumulated masses of soil such as the gunpowder depot buried underground for over than 50 years, the intact Ottoman underground cistern and its system of gutters.
\end{abstract}

Keywords: fortification, Ottoman, rampart, history, restoration, monument, Algeria, Kabylie.

\section{Introduction}

The fortress at Bouira, known as Bordj Hamza, is located in the Kabylie region, a mountainous area formerly occupied by proud and independent Kabyle tribes 
and the only area in Algeria unoccupied by the Ottoman power in the $16^{\text {th }}$ and the $19^{\text {th }}$ Centuries. It is situated on the Algiers-Constantine main road at the point where the roads from Beylik in the east, sour el Ghozlane and Biskra meet. It protected the territories of Beni Djaad and the access to Beylik of Titteri. It appears to have been built in the $16^{\text {th }}$ Century during the reign of the pasha Hassan Corso who, between 1540 and 1541, ordered the introduction of several fortified strong holds at strategic points within the Constantine territory.

During the period of French colonialism, the town of Bouira developed around the fortress bordj Hamza and today, it is situated in a residential area, Draa el Bordj, to the south of the town. The fortress, built on a dominant hillside, overlooks the rest of the town. It is surrounded by individual dwellings in the north and a cemetery and agriculture land in the south (Fig. 1).

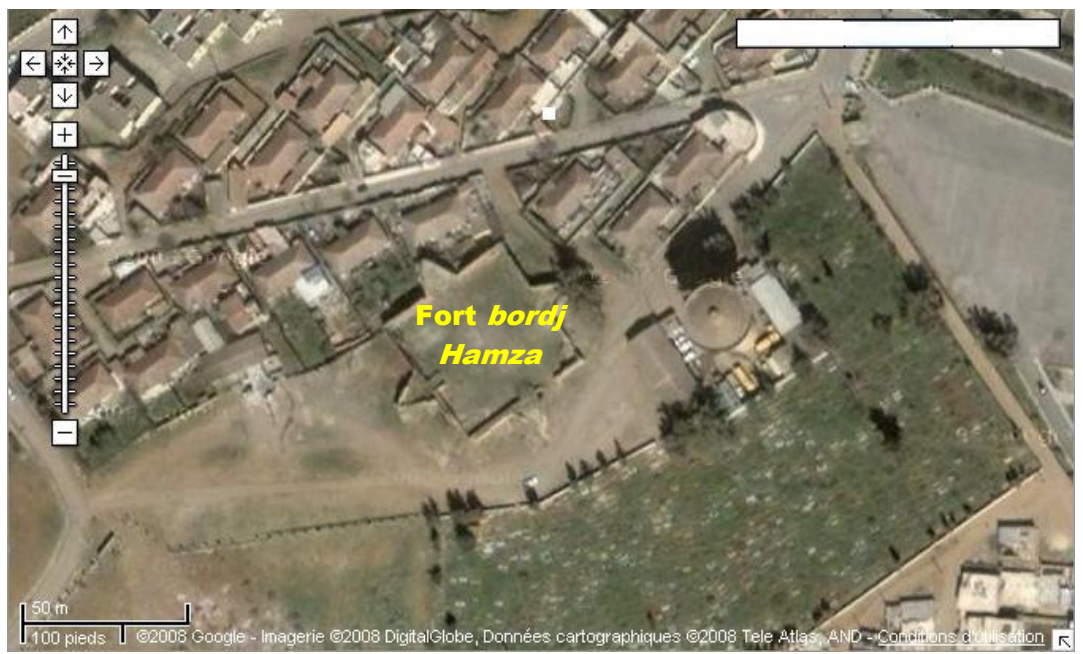

Figure 1: $\quad$ Bordj Hamza in Bouira-2010.

Very few documents about this edifice exist. Only the records of the French army after 1830 describe its aspect, its architecture and its transformation.

The study of the fortress is a project put forward by the Ministry of Culture which decided to proceed with the restoration of archeological and historical edifices in the region of Bouira after they were listed by the cultural heritage. This study is based on an overall methodological approach following the directives laid down in the law 98-04 of April $4^{\text {th }} 1998$ which defined the operations for the protection, restoration and re-evaluation of existing historical sites. They are four in number.

Urgent work and fortifications;

Architectural survey and historical development;

Pathologies and diagnostics;

Restoration. 


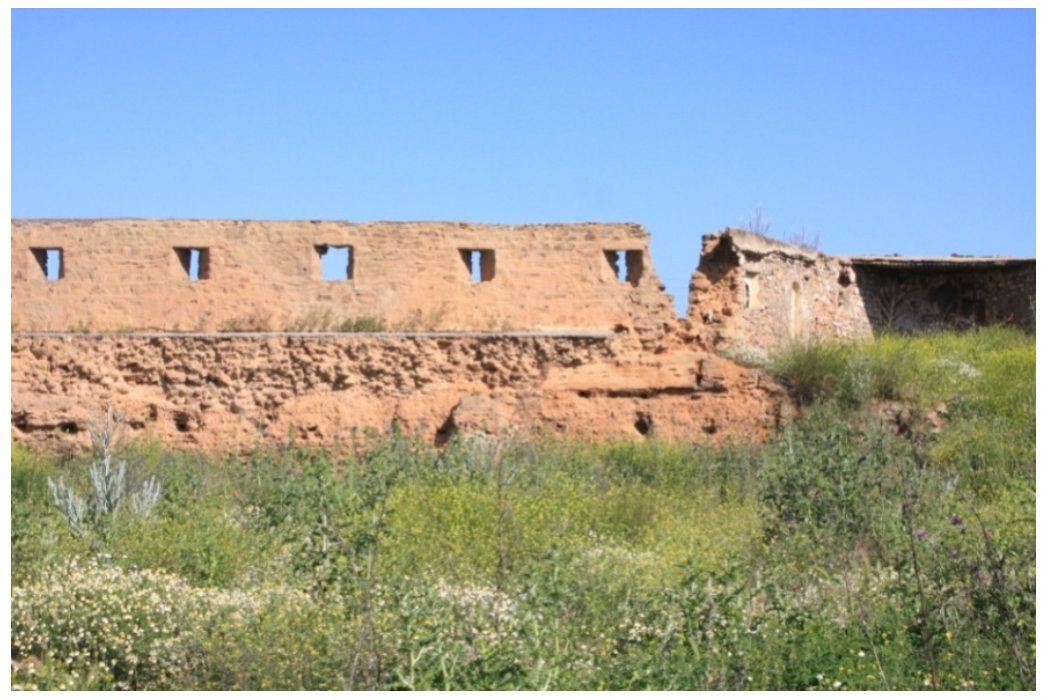

Figure 2: $\quad$ Bordj Hamza before restoration work.

\section{Urgent works}

The first task was to tackle the most urgent problems which put the monument at greatest risk. (For example: very unstable walls that could collapse at any moment, the built up of debris and rubbish, the overgrowth of vegetation in the masonry; squatters and the theft of stones).

The preliminary operation in the conservation of the fortress were the cleaning away of debris, rubbish and mounds of earth that had accumulated over several dozens of years and the cleaning and weeding of the interior of the fort and its borders. The walls were stripped and replastered with cement, iron bars, wooden supports and colonial-style buttresses of stone. Cement and concrete were erected in the interior angle of the north east bastion.

Masses of cement stuck to floor coverings were cleaned away to allow the process of survey and pathological study to take place in the best possible conditions.

\section{Historical developments}

During the period of the Ottoman Regency, this fortress was the theatre of several battles (example: the war between the caliph of Medjana and the Pasha Hassen 1552 to 1554; the offensive of local tribes August $25^{\text {th }} 1756$ ) in 1775 the fortress was reinforced after attack by Kabyle tribes. Due to its strategic territorial position, the Ottoman authorities placed 62 soldiers there; divided into four troops of 15 to 16 men under the command of an officer with the rank of "agha". Its artillery was an arsenal of 6 to 8 cannons (Al-Bakrî[1]). 
in 1839 when the French expedition "Portes de Fer" moved through the Kabylie region to occupy the town of Constantine, the artist Adrien Dauzat, travelling with the army, made two sketches of the fortress which not only capture its charm but give an idea of its appearance both interior and exterior, before its occupation by the French army (Dauzat [2]).

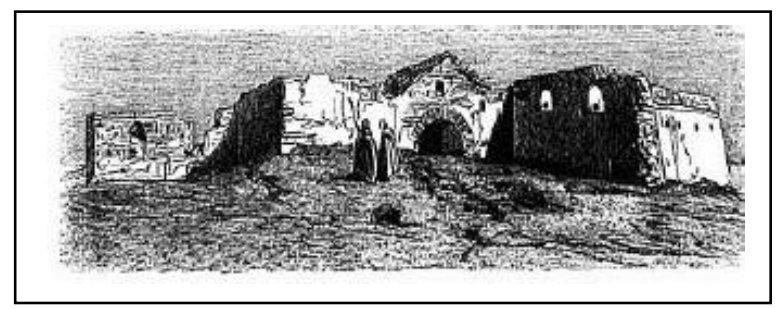

Figure 3: $\quad$ Bordj Hamza by A. Dauzat in 1839.

In 1848 the fortress was occupied and restored by the French army which made it into a barracks for its troops in the town of Bouira.

The main dates that stand out as landmarks in the history of its building and its repairing are presented in the chronological table that follows:

Table 1: $\quad$ Landmark dates.

\begin{tabular}{|c|c|}
\hline $1540-1541$ & Fort's foundation \\
\hline $1552-1554$ & Partial destruction of the fort \\
\hline 1775 & Reconstruction and reinforcement \\
\hline 1847 & Restoration by the French army \\
\hline 1896 & Extension of the underground tank \\
\hline 1906 & Location of the fort to civilians \\
\hline 1936 & The fort was sold to the civil authorities \\
\hline 1962 & The fort was abandoned \\
\hline 2003 & The fort was squatted and turned into a slum \\
\hline 2011 & Works of restoration \\
\hline
\end{tabular}

\subsection{Architectural description in 1848}

In 1848 the plan of Bordj Hamza shows a centralized organization of the fortress (Pornain [3]). The general appearance of the enclosure is a square, showing redans, in the form of isosceles triangles in the middles of each side, which can be reached by interiors slopes. Access to the fortress is an arched porch comprising on the one hand, a bench and a small window overlooking the passageway and on the other hand two doorways leader to two rooms, the guard room and the visitors' room. The great square courtyard which covers two thirds of the surface gives onto long spaces which run lengthwise around the outside of the enclosure. According to the key on the plan established by military engineers these spaces take priority: 
The four bastions (code:1 35 7) the pointed redans (code 2468 ) the porch et the main gateway (code: 33 and 11) the guard room (27) and visitors room (28).

On the south east side, north side and north west side can be found the living quarters (19 24252930 ) the chief's of officer's quarters (18) a stable for five horses (20) the pantry, the oven and the floor depot (21 22 23); a gunpowder store in the east angle (26) the opening to an underwater cistern (31) and the only staircase of the fortress leading to the platform above the gunpowder store (32).

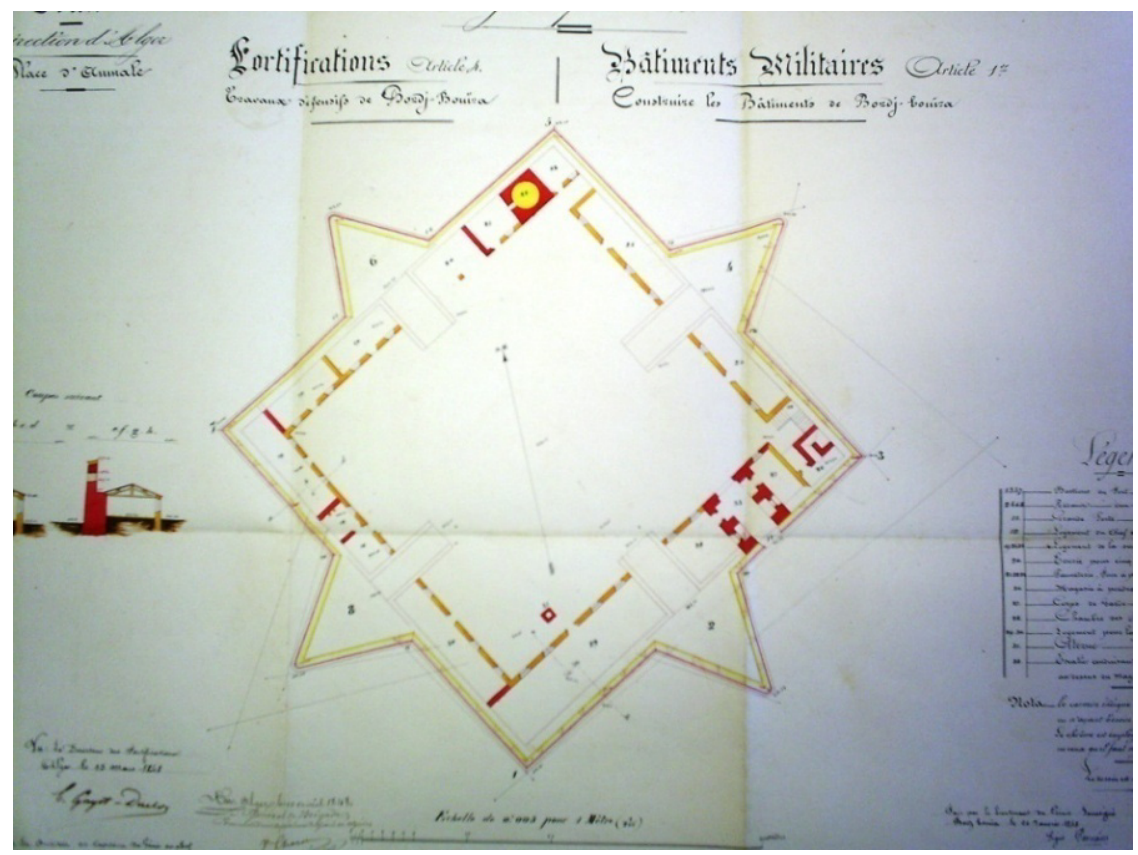

Figure 4: $\quad$ Plan and restoration project in 1848 by the French army.

\section{Today's survey}

We use topographic techniques known as "nuage de points", a procedure that allows each reliable point in the area to be traced through three separate reference coordinates serving to construct, not only the different plans of the edifice but also its elevations (Bouteflika [4]).

\section{Pathology}

The fortress has largely fallen to ruin due to its abandonment during several decades. Only the exterior wall and its bastions are still standing but even these show signs of degradation. The principal causes are abandonment, the loss of preventive practices even the absence of upkeep; the hazards of time and clumsy attempts at reparation. 


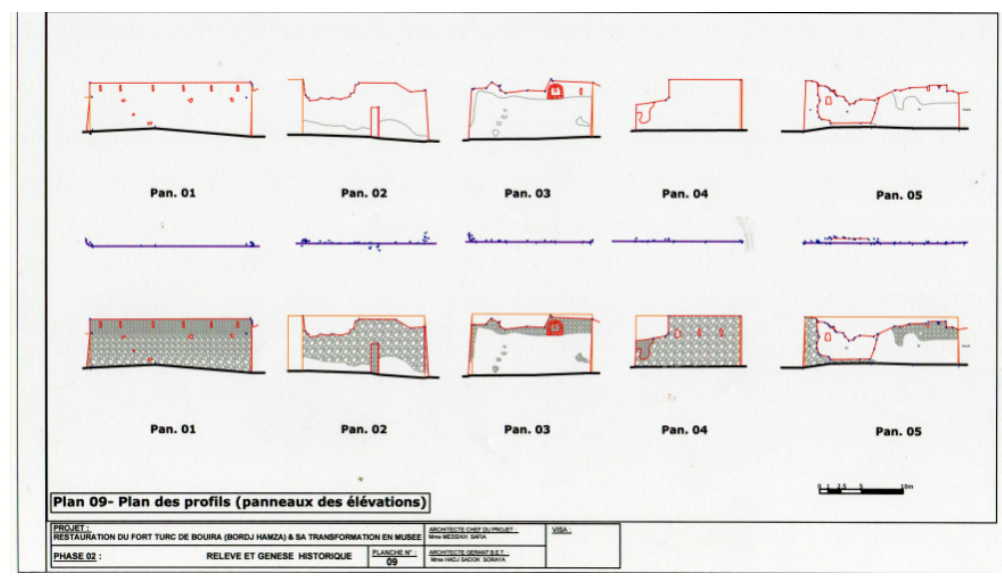

Figure 5: $\quad$ Bordj Hamza's survey in 2008.

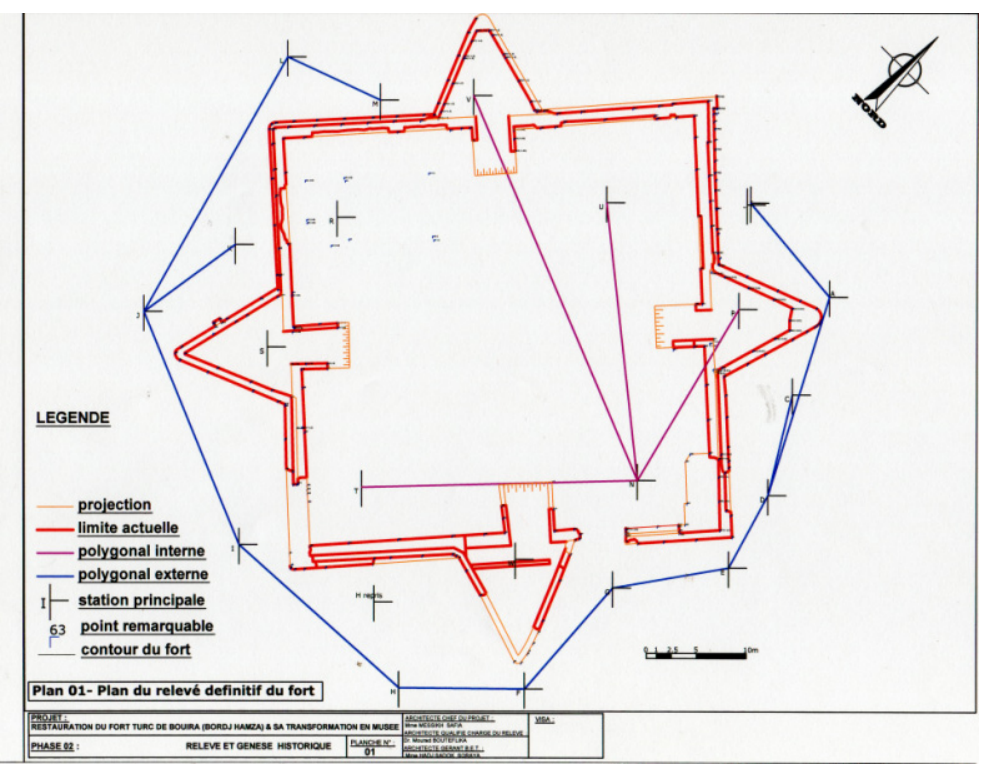

Figure 6: $\quad$ Bordj Hamza’s survey in 2008.

The fortress was abandoned after independence and its stones became the subject of re-use. Equally, during the 1990s, it became increasingly used as a precarious dwelling place. Over time the deterioration of the original material, rainwater damage and leaking drains led to loss of cohesion in the walls and their partial collapse. In addition several types of vegetation have developed along the walls and floors, seriously aggravating the stability of the structures. The principal pathologies have been carefully indicated in the plans showing the different portions of the enclosure walls. In the absence of ceilings, the walls have taken full weight of the damage. 


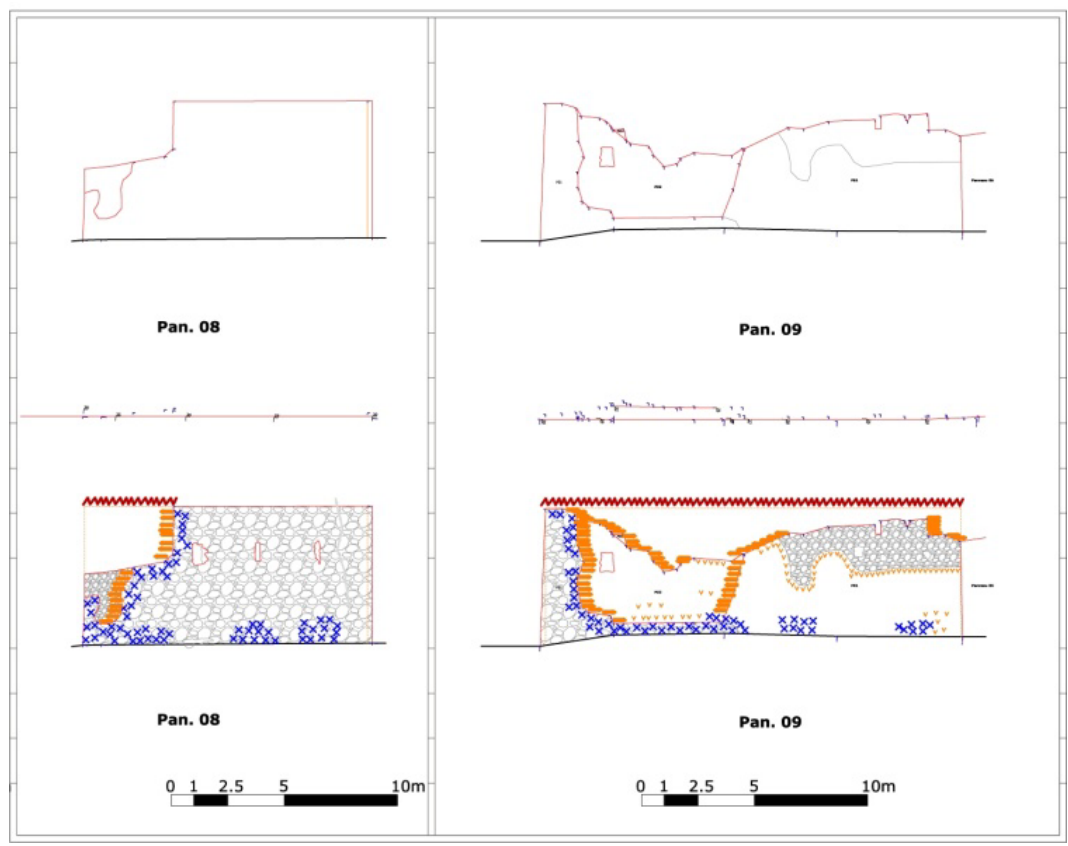

Figure 7: $\quad$ Profile plan. Examples of pathologies.

\section{Restoration}

The restoration works at the fortress, following the recommendations laid down in the charters of the International Heritage Trust, had the following characteristics. Firstly the original material was preserved as much as possible by re-using stones salvaged in the clean-up operation throughout the fortress. Traditional material and techniques were used in the reparation work. Samples of brick, stone and mortar were analyzed in the laboratory (Hamiane [5]) in order to ensure that the composition of the mortar used to repair the walls was close to the original as possible. This was found to be made of limestone, sand, brick and earth, a composition used extensively throughout Algeria during the Ottoman period. Secondly reconstruction was made only when it was judged necessary for reasons of stability such chaining, or to give an idea of the unity of the edifice. As most of the rooms in the fortress have disappeared, only the outside wall is the object of the restoration. This is composed of a double wall of mixed masonry dating back to the Ottoman period and a store wall from the time of the French occupation, which was in itself a restorative operation.

In 1848, the French military engineers surrounded the fortress with a second store wall built back to back with the first (fig. 8) increased its height and crowned it with battlements and apertures for their canons (fig. 9). As the Ottoman wall remained mostly protected on its outside face, the consolidation work today concerns the parching up of the French wall on the exterior face of 
the fortress. The destruction of the interior spaces has been responsible for the instability of the ramparts which have partially collapsed. Restoration work included operations of consolidation on the ramparts by physically replacing the damaged parts (reconstruction of portions of the walls with the same material). The reconstruction was made in the distinct manner of the original structure from the size of the stones used to the color of the mortar. Even the way in which they were laid has been carefully imitated. Conservation work was done step by step beginning by the cementation (Brenda [6]) of the walls by liquid limestone, the laying of a periphery drain, the patching up of cracks, the reconstruction of partly crumbled walls for chaining and the restitution of the south-east redan (following record photo) Afterwards, excavation revealed archeological traces of the Ottoman gunpowder depot; floor covering of places no longer in existence and also circular traces of a bread oven from the Ottoman period.

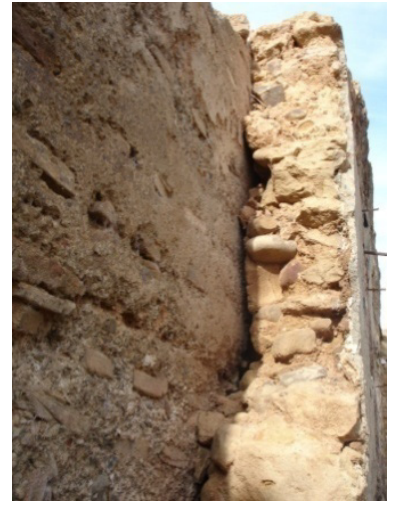

Figure 8: French and Ottoman back to back wall.

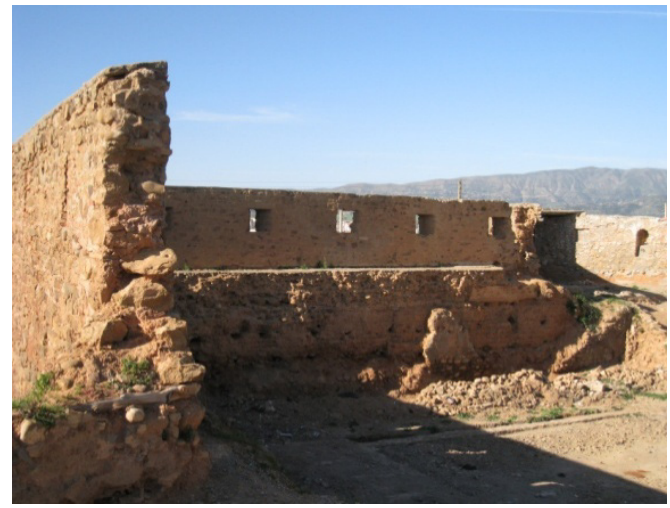

Figure 9: French battlements and apertures.

The operation of the cementation of the walls using a fluid mortar of limestone base was done from top to bottom and by successive layers until the whole of the interior cavities was filled (fig. 10).
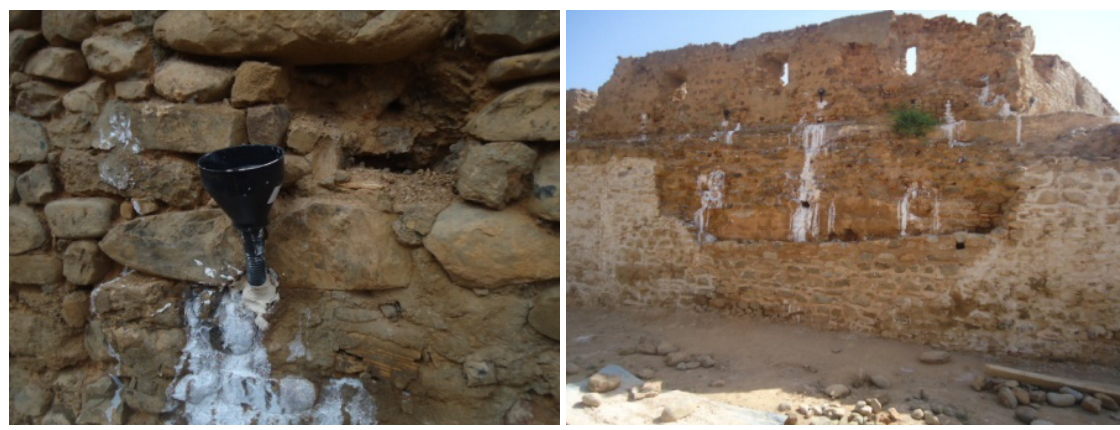

Figure 10: Funnel used for filling liquid mortar into the walls. 
The second operation consisted of strengthening the walls by filling a "banchage" with the same materials of the original and reconstructing holes in the masonry (figs. 11, 12).

Then the operation of consolidation to physically replace damaged parts (reconstructing portions of the walls by using the same material) (figs. 13-15).

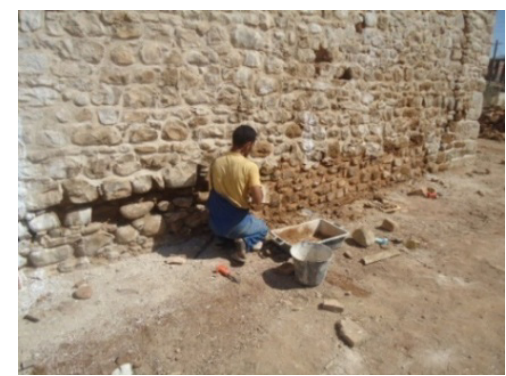

Figure 11: Reconstruction of fragments of crumbled masonry.

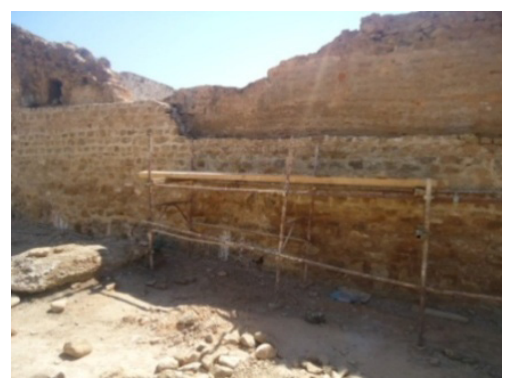

Figure 13: Repair of the outside Figure 14: Repair of deep crack. French wall.

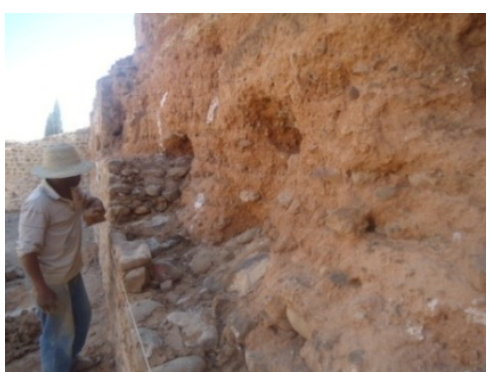

Figure 12: Reconstruction of the inside Ottoman rampart.

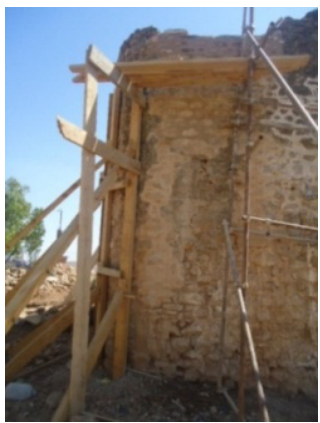

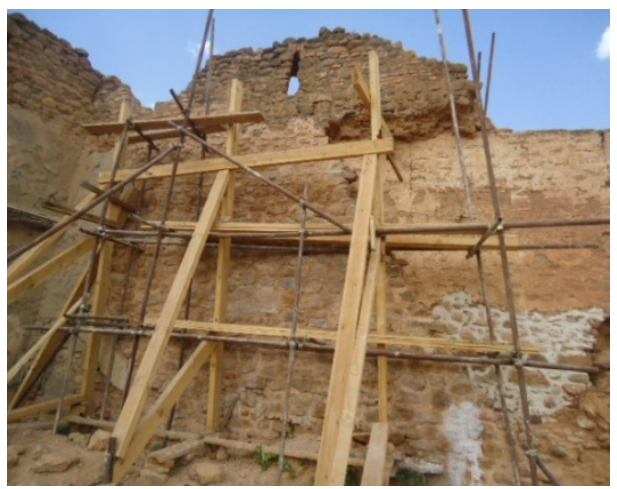

Figure 15: The wall fragments were reconstructed using a masonry of rough stones continuity of existing materials and joints. 
As for the pointing of the masonry, the existing joints were rubbed down $3 \mathrm{~cm}$ by hand then a limestone based mortar was spread along the thickness of the cavities and smoothed out in such a way so as to avoid protuberance of the mortar (fig. 16) followed by laying a periphery outside drain to avoid leaks (fig. 17).

Another step was the total cleaning and jointing of the walls of the Ottoman underground cistern or djeb (fig. 18) as well as the restoration of its access (fig. 19).

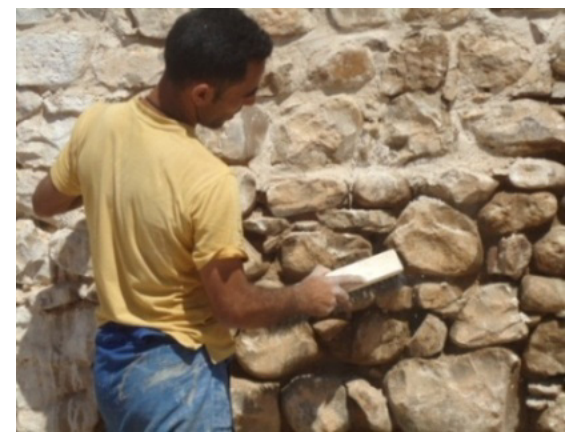

Figure 16: Repair of joints.

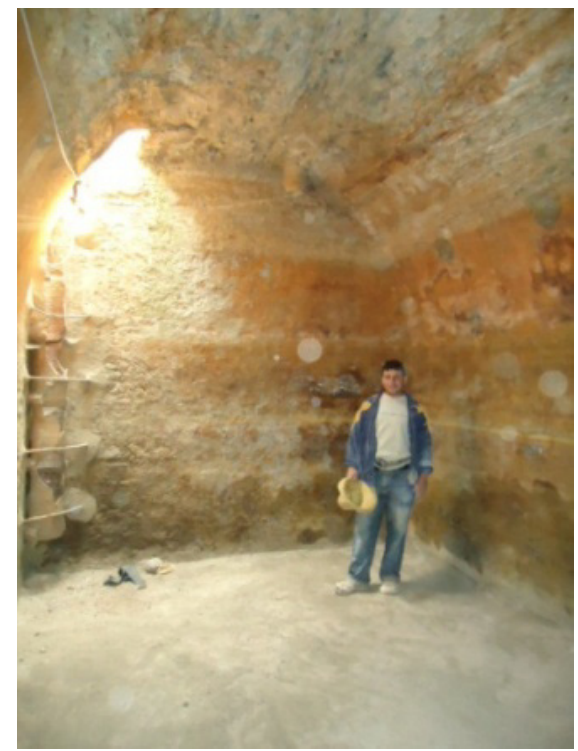

Figure 18: The Ottoman underground cistern.

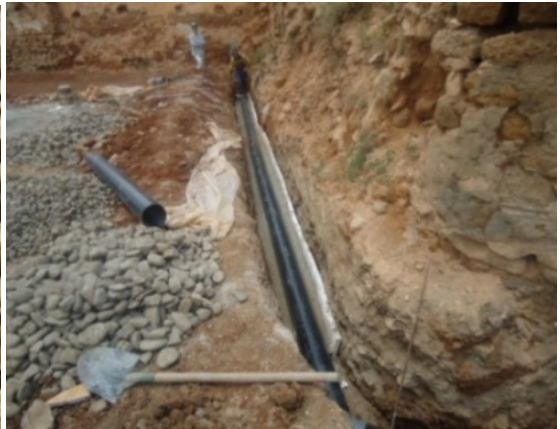

Figure 17: Laying of the periphery drain.

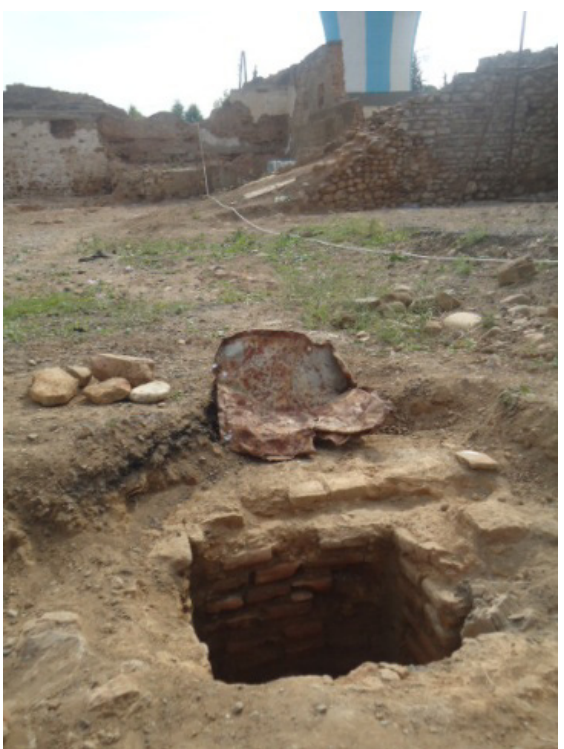

Figure 19: The cistern access. 
The top of the walls are stabilized by repairing and restoring the masonry with a line of curved bricks (fig. 20). Treatment of the battlements and canon apertures consisted of a cleaning operation. The stones and bricks were brushed and the most damaged were replaced (fig. 21). Finally the contour line was restored by a limestone based mortar.

Excavation and clearing away of the soil in the eastern angle of the fortress brought to light three low boundary walls; not exceeding $1.20 \mathrm{~m}$ in height, along three sides of the gunpowder depot (fig. 22).

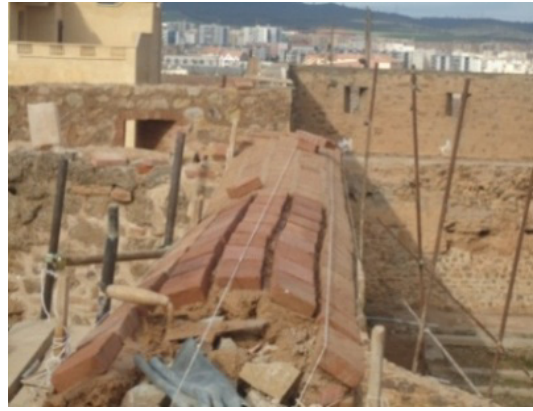

Figure 20: Curved brick to repair the top of the walls.

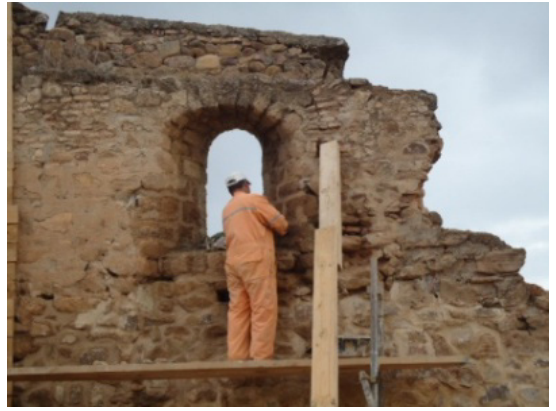

Figure 21: Treatment of the battlements and canon apertures.

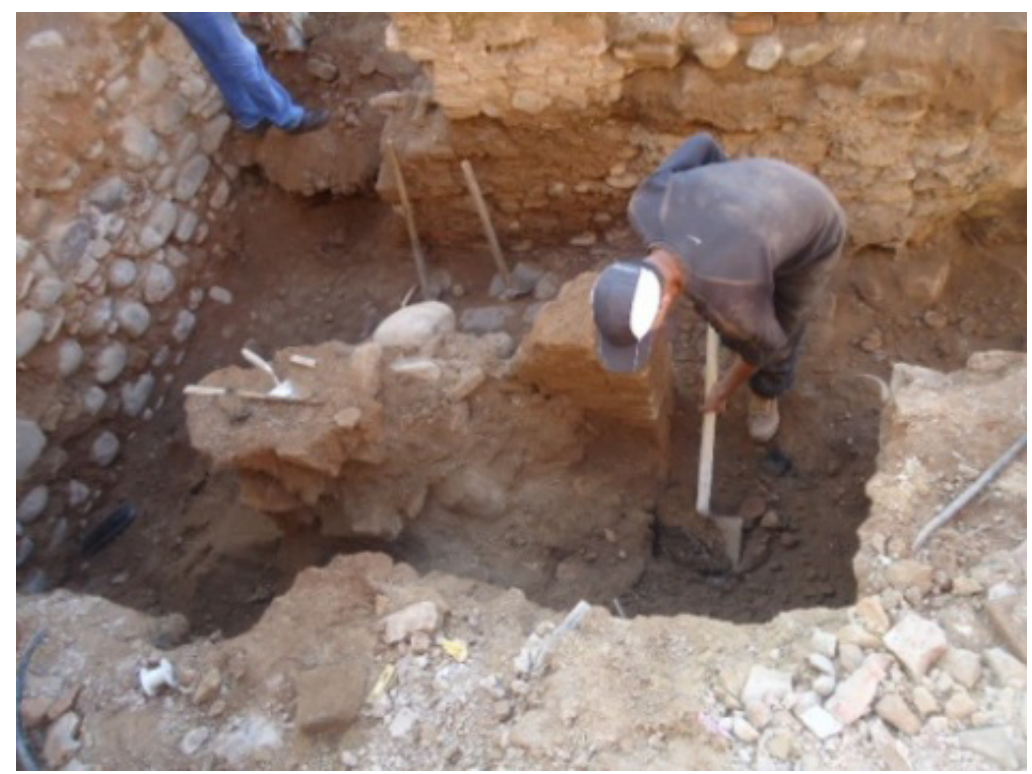

Figure 22: The brought to light of the gunpowder depot. 
38 Defence Sites

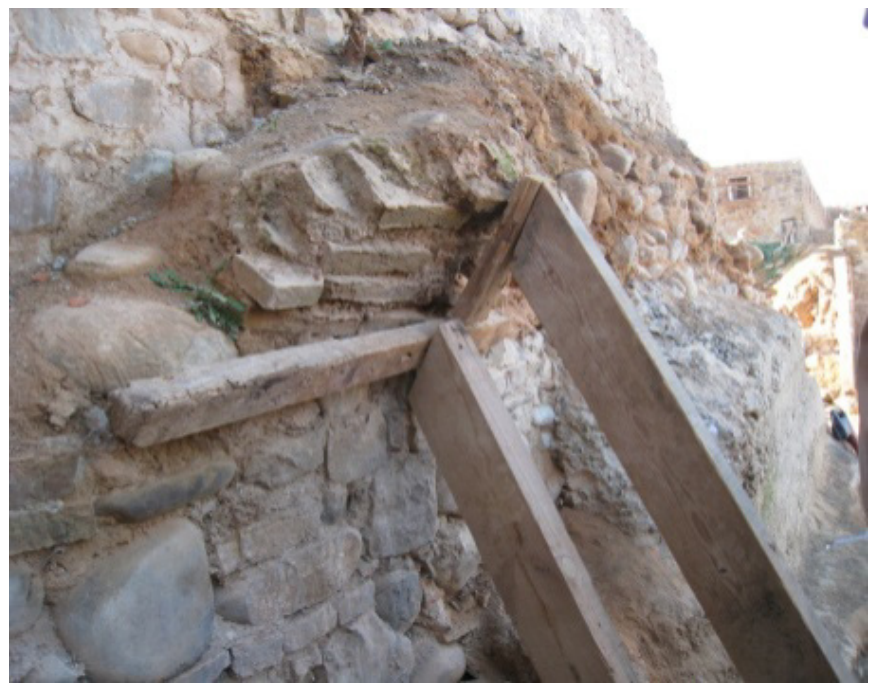

Figure 23: In the entrance to the depot a fragment of a semi-circular archway was equally uncovered.

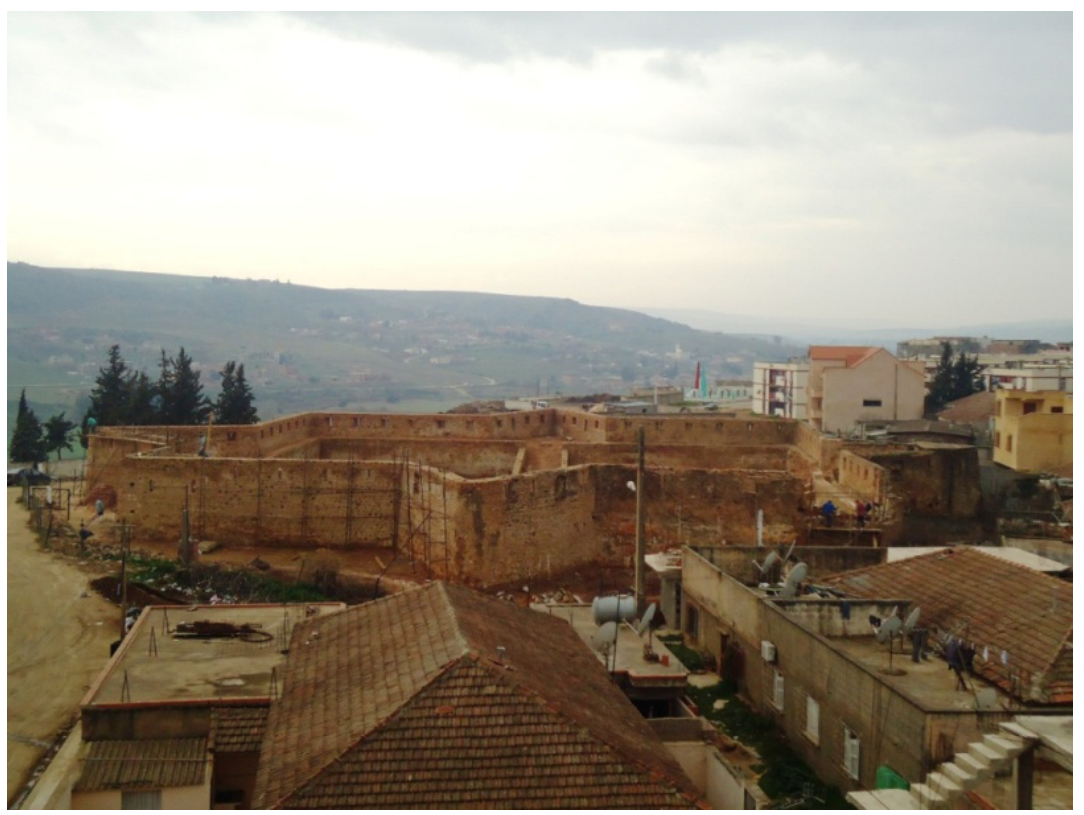

Figure 24: The general appearance of Bordj Hamza during the restoration in January 2012. 


\section{References}

[1] Abou Obeïd Al-Bakrî, Kitab al masalik wa-l-mamalik [The Book of Roads and Kingdoms], éd. critique en arabe par Adrian van Leeuwen et André Ferré, Carthage, 1992, 2 vol Abū 'Ubayd 'Abd Allāh ibn 'Abd al-'Azīz Bakrī, al-Maghrib fì dhikr bilād Ifrīqūyah wa-al-Maghrib : wa-huwa juz' min kitāb al-Masālik wa-al-mamālik, Baghdad, c. 1968.

[2] Sketch of Adrien Dauzat in 'Journal de l'expédition des 'Portes de Fer'. Imprimerie royale Paris 1844 réédité par Charles Boyer 1995 p :272-273.

[3] Lt Pornain “Defensives' Works of bordj Bouira" Aumale box n1 (18461848) Project for 1848. sheet No8. Records of SHD 1VH144. Department of the Army (DAT) Genie, site of Aumale. Château de Vincennes Paris.

[4] Survey done by Dr Architecte Mourad Bouteflika in June 2008.

[5] Pr Hamiane "analysis and expertise report in building materials of Bouira Turkish Fort” M'Hamed Bougara University. Faculty of Engineering Sciences. Boumerdès 2011.

[6] Pietro Brenda "Masonry Buildings: Analysis of static imbalance and consolidation techniques," Centro Analisi Sociale Progetti, Roma 1993.

[7] Sisto Mastrodicasa Disesti statici delle strutture edilizie, éditions Hoepli, Milan, 1978 Milan. 